\title{
Environmental drivers and composition of assemblages of immature odonates (Insecta) in a subtropical island in southern Brazil
}

\author{
Preditores ambientais e composição de comunidades de imaturos de Odonata (Insecta)
} em uma ilha subtropical do Sul do Brasil

Mateus Marques Pires ${ }^{1 *}$ (D), Ana Emília Siegloch² (D), Malva Isabel Medina Hernández ${ }^{3}$ (D) and Maurício Mello Petrucio ${ }^{3}$

${ }^{1}$ Laboratório de Ecologia e Conservação de Ecossistemas Aquáticos, Universidade do Vale do Rio dos Sinos - UNISINOS, Avenida Unisinos, 950, CEP 93022-750, São Leopoldo, RS, Brasil

${ }^{2}$ Programa de Pós-graduação em Ambiente e Saúde, Universidade do Planalto Catarinense UNIPLAC, Avenida Castelo Branco, CEP 88509-900, Lages, SC, Brasil

${ }^{3}$ Departamento de Ecologia e Zoologia, Programa de Pós-graduação em Ecologia, Centro de Ciências Biológicas, Universidade Federal de Santa Catarina - UFSC, CEP 88040-900, Florianópolis, SC, Brasil

*e-mail: marquespiresm@gmail.com

Abstract: Aim: Describe the diversity of immature stages of Odonata (Insecta) in streams from a subtropical island in southern Brazil and investigate the influence of environmental variables on the composition of their assemblages. Methods: Eleven low-order streams (1st to 3rd order) were sampled in two conservation units located in the island of Santa Catarina (southern Brazil) between 2010 and 2012. Immature specimens of Odonata were collected using a Surber sampler. The influence of water abiotic parameters and habitat structure (mesohabitats: riffle vs. pool areas, microhabitats: litter vs. stone substrates) on the composition of Odonata was tested through the seasons using ordination diagrams and redundancy analysis. Results: Nine odonate genera from seven families were recorded in the study region. The genera Desmogomphus, Epigomphus (Gomphidae), Heteragrion (Heteragrionidae) and Perilestes (Perilestidae) have their first records described for the state of Santa Catarina. Additionally, biological notes are provided for other odonate genera concerning substrate use. The composition of Odonata communities changed over the seasons and they were influenced by water temperature and velocity. Additionally, odonate composition differed significantly between microhabitats (substrate type) and mesohabitats (riffle vs. pool areas) in the streams studied. Conclusions: The lower genera richness of Odonata recorded in the island of Santa Catarina in relation to other Brazilian subtropical streams is probably associated with the insular condition of the study region. This study also demonstrated that substrate (organic and inorganic) and mesohabitat (riffle and pool) types were important drivers of the composition of the fauna of immature odonates, evidencing the role of climate and habitat structure in influencing subtropical stream insect communities.

Keywords: aquatic insects; Odonata; insular fauna; streams; habitat structure.

Resumo: Objetivos: Descrever a diversidade de estágios imaturos de Odonata (Insecta) em riachos de uma ilha subtropical no sul do Brasil e investigar a influência de preditores ambientais sobre a composição de suas comunidades. Métodos: Onze riachos de baixa ordem (entre $1^{\text {a }}$ e $3^{\text {a }}$ ordem) foram amostrados em duas unidades de conservação localizadas na ilha de Santa Catarina entre 2010 e 2012. Indivíduos imaturos de Odonata foram coletados com amostrador tipo Surber. A influência de parâmetros abióticos da água e da estrutura de habitat dos riachos (mesohabitats: trechos de corredeira vs. remanso; microhabitats: substratos folhiço vs. pedra) sobre a variação sazonal da composição de 
Odonata foi testada através de diagramas de ordenação e análise de redundância. Resultados: Nove gêneros pertencentes a sete famílias de Odonata foram registrados na regiáo de estudo. Os gêneros Desmogomphus, Epigomphus (Gomphidae), Heteragrion (Heteragrionidae) e Perilestes (Perilestidae) são registrados pela primeira vez no estado de Santa Catarina. Adicionalmente, novas anotaçóes biológicas em relação ao uso do habitat são registradas para outros gêneros. A composição das comunidades de Odonata variou sazonalmente e foram influenciadas pela temperatura da água e vazáo. Adicionalmente, a composição da fauna diferiu significativamente entre trechos de corredeira e remanso e entre tipos de substrato nos riachos amostrados. Conclusóes: A menor riqueza de gêneros de Odonata registrada na ilha de Santa Catarina em relação a outros riachos subtropicais brasileiros deve estar relacionada à condição insular da região de estudo. Além disso, este estudo demonstrou que os tipos de substrato (orgânicos e inorgânicos) e de mesohabitat (corredeira e remanso) foram importantes preditores ambientais da composição da fauna de imaturos de Odonata, evidenciando a influência do clima e da estrutura de habitat sobre as comunidades de insetos de riachos subtropicais.

Palavras chave: insetos aquáticos; Odonata; fauna insular; riachos; estrutura de habitat.

\section{Introduction}

The distribution of insect assemblages in lotic ecosystems is influenced by several environmental drivers. Stream insects are affected by local-scale drivers such as substrate type, water physicochemical parameters and riparian vegetation features. Thus, the structure of insect assemblages is associated with the habitat structure and ecological integrity of running waters (Allan \& Castillo 2007; Thorp \& Covich, 2010; Mendes et al., 2017). However, streams have become one of the most threatened ecosystems throughout the world, facing several kinds of impacts, such as damming, riparian vegetation removal and urban development (Allan \& Castillo 2007). These processes are assumed to be prominent in island regions due to spatial delimitations (March et al., 2003; Ramírez et al., 2012). Furthermore, stream island insects are influenced not only by habitat characteristics, but they are also associated with spatial processes related to isolation, common to the fauna from insular areas (Thorp \& Covich, 2010). Nevertheless, the knowledge on the ecology of stream insects from tropical and oceanic islands is far more developed than in temperate and continental ones (New, 2008; Thorp \& Covich, 2010; Ramírez et al., 2012; Longo \& Blanco, 2014).

Odonates occur in streams in their immature stages, and they are important representatives of the trophic structure in these ecosystems due to their predatory feeding mode (Corbet, 2004). Immature stages of odonates have a diverse range of life habits and ecological requirements, thus the assemblage structure of immature odonates is influenced by several habitat characteristics, such as water current, water abiotic conditions and microhabitat type (Hofmann \& Mason, 2005; Suhling et al., 2015). The sensitiveness of the immature stages of
Odonata to changes in stream habitats makes them reliable indicators of stream ecological integrity (Mendes et al., 2017).

However, the fauna of Odonata of the Neotropical region is considered the least studied in the world (Kalkman et al., 2008). In Brazil, the largest country in the region, more than 800 species are described (Pinto, 2019). In subtropical regions of the country the diversity of Odonata is poorly known (Marco Junior \& Vianna, 2005), generally limited to spatially restricted inventories (Pires et al., 2013; Figueiredo et al., 2013; Renner et al., 2016a, b). Furthermore, the knowledge on their ecological relationships with environmental drivers is even scarcer. The few ecological studies available conducted in tropical Brazilian streams show that substrate type (organic vs. inorganic) and water quality are important drivers of odonate composition (Carvalho \& Nessimian, 1998; Delgado, 2002; Assis et al., 2004; Soares et al., 2015).

In this study, we present the inventory of immature stages of Odonata found in streams running through conservation units from a large subtropical continental island in southern Brazil. We also assess the influence of local environmental drivers related to habitat structure and water abiotic parameters on the composition of odonate assemblages. Therefore, this study aims at contributing to the knowledge of the diversity and ecological relationships of the aquatic fauna in insular freshwater ecosystems of Brazil.

\section{Material and Methods}

\subsection{Study region}

The study region is located in Santa Catarina Island, southern Brazil (state of Santa Catarina, Figure 1). The climate in the island is Cfa of Köppen 


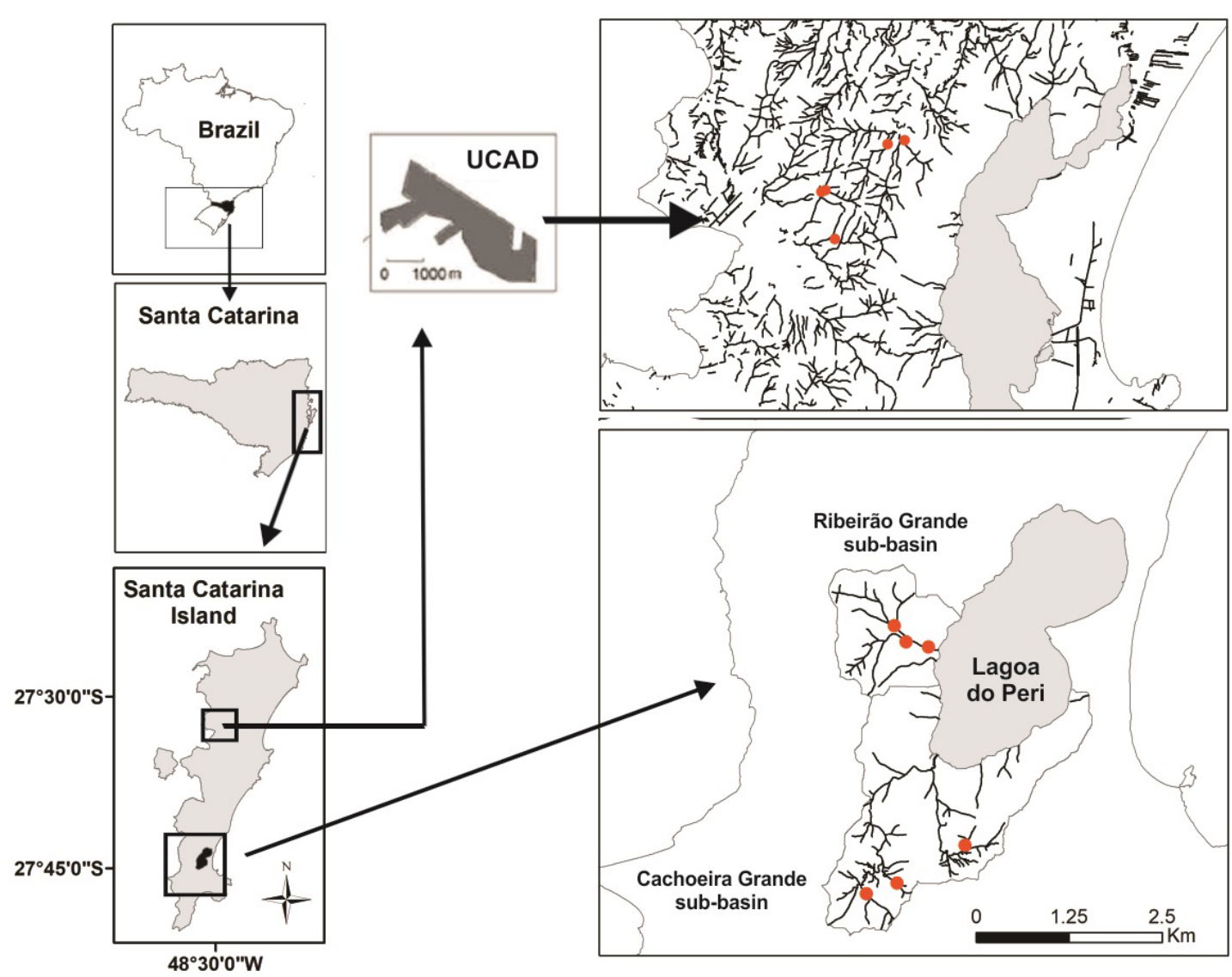

Figure 1. Location of the studied streams (orange circles) in Santa Catarina Island, southern Brazil.

(humid temperate) without a marked dry season (Nascimento, 2002). The average annual rainfall is $-1400 \mathrm{~mm}$ (INMET, 2018), although higher rainfall is historically recorded in warmer periods of the year (from December to March; Lisboa et al., 2015). The average temperatures range from -16 to $-20^{\circ} \mathrm{C}$ in the colder seasons (autumn and winter), and from -23 to $-26^{\circ} \mathrm{C}$ in the warmer ones (spring and summer) (Fontes et al., 2015).

Two conservation units in the island were selected for the study (Figure 1): (1) The Municipal Park of Lagoa do Peri (PMLP; $27^{\circ} 44^{\prime}$ S; $\left.48^{\circ} 31^{\prime} \mathrm{W}\right)$. The PMLP has an area of $-2,000$ ha and holds the largest freshwater reservoir in the island. The landscape is characterized by restinga vegetation in the coastal plains and primary ombrophilous forest next to the headwaters $(-280 \mathrm{~m}$ a.s.l.; Santos et al., 1989). (2) The Desterro Environmental Conservation Unit (UCAD; $27^{\circ} 31^{\prime} S$; $\left.48^{\circ} 30^{\prime} \mathrm{W}\right)$. The UCAD has an area of -490 ha covered by Ombrophilous Forest fragments in different succession stages (Bonnet \& Queiroz, 2006).

In the PMLP, six low-order streams $\left(1^{\text {st }}\right.$ to $3^{\text {rd }}$ order; two streams of each order) distributed in two sub-basins (Cachoeira Grande and Ribeirão Grande) were seasonally sampled from 2010 to 2011 (May 2010: autumn; August 2010: winter; November 2010: spring; February 2011: summer). In the UCAD, five stream reaches were sampled in the summer of 2012 (February) (Figure 1). Family-level studies on aquatic insects have been conducted in these areas by Pires et al. (2015) and Siegloch et al. (2016).

\subsection{Sampling methods and specimen identification}

In each stream, immature odonates were collected with a Surber sampler (area $=361 \mathrm{~cm}^{2}$; mesh size $=0.25 \mathrm{~mm}$ ) in riffle and pool mesohabitats (reaches). In each mesohabitat, four subsamples were taken in litter and stone substrates and posteriorly pooled into a sample. In the laboratory, the sampled material was sorted in a $0.25-\mathrm{mm}$ mesh sieve. Odonate specimens were collected under a stereomicroscope and identified to genus level whenever possible using specialized literature (Costa et al., 2004). The assignment into families of the genera found was based on the nomenclature and classification system proposed by Dijkstra et al. 
(2014). Odonates were fixed and preserved in $80 \%$ ethanol and stored in the collection of the Laboratório de Limonologia of the Universidade Federal de Santa Catarina (Florianópolis, Santa Catarina, Brazil).

\subsection{Data analysis}

\subsubsection{Inventory}

The accumulated richness was estimated by the collector's curve. The curve was obtained with 500 curves generated by random addition of samples. In view of the standardized sampling design in the PMLP, the collector's curve was built using the samples of this dataset only. For this analysis, the samples were pooled according to substrate type $(\mathrm{N}=96)$.

\subsubsection{Influence of habitat structure and water abiotic parameters on the composition of Odonata}

In the riffle mesohabitats of the PMLP, the following water abiotic parameters were measured with a YSI Model multi-parameter water quality meter: water temperature $\left({ }^{\circ} \mathrm{C}\right) ; \mathrm{pH}$; electrical conductivity ( $\mu$ S.s-1); and dissolved oxygen (mg.L-1). In addition, the following habitat structure variables were measured at each stream: water depth $(\mathrm{m})$ and stream width $(\mathrm{m})$ with a measuring tape and water velocity (m.s-1) using the floatmethod (Bain \& Stevenson, 1999). To assess the influence of the water abiotic parameters and habitat structure variables on odonate composition, we employed a redundancy analysis (RDA, Legendre \& Legendre, 2012). On account of the seasonal sampling design, we first ran a non-parametric multivariate analysis of variance (PERMANOVA) to test for variation in the explanatory variables (standardized values) among seasons. As a significant variation among seasons was detected (pseudo-F $=94.534 ; \mathrm{R}^{2}=0.934$; $\mathrm{P}=0.005)$, seasons were included in the RDA. Prior to the RDA, we ran pre-selection procedures on the matrix of environmental variables (standardized values); in this procedure, the significance value used for inclusion of a parameter was 5\% along with adjusted explained threshold value of 0.1 (Blanchet et al., 2008). This procedure retained the following variables: water temperature, water velocity and stream width, and they were included (along with seasons) as predictor variables in the $\mathrm{RDA}$. The odonate composition matrix was based on the pooled data of the substrate samples $(\mathrm{N}=24)$ and transformed by the relative abundance prior to the RDA. Finally, we assessed the explained variance of the models using $\mathrm{R}^{2}$ adj, values, and the significance of the model using randomization tests (999 permutations) (Peres-Neto et al., 2006).

We first assessed the influence of mesohabitat (riffle and pool) and microhabitats (litter and stone substrate types) on the composition of Odonata through non-metric multidimensional scaling (NMDS) ordination diagrams. Statistical differences in the composition of Odonata between mesohabitat and microhabitats were tested by taking into account the repeated-measures design of the study. For this purpose, we ran a PERMANOVA using seasons as blocking factor (randomized-block PERMANOVA; 9999 permutations). The ordination diagrams and the PERMANOVA were based on the full dataset of the PMLP $(\mathrm{N}=96)$. The dissimilarity matrix used was generated with the Bray-Curtis coefficient applied to the relative abundance matrix of odonate taxa. All statistical analyses were conducted with the vegan package (Oksanen et al., 2016) in the $\mathrm{R}$ environment version 3.3.3 ( $\mathrm{R}$ Core Team, 2017).

\section{Results}

We collected 212 specimens from seven families and nine genera in the studied streams 185 in the PMLP; 27 in the UCAD). The suborder Anisoptera was represented by three families and six genera, while the suborder Zygoptera, by four families and three genera (Calopterygidae specimens could not be identified to genus level). Gomphidae was the richest family (three genera). The dominant genera in the study region were Heteragrion Selys, 1862 (Heteragrionidae) (24.3\%), followed by Rhionaeschna Förster, 1909 (Aeshnidae) (18.4\%) and Brechmorhoga Kirby, 1894 (Libellulidae) (14.1\%). Immatures of Calopterygidae corresponded to $24.1 \%$ of the total number of specimens collected (Table 1). The collector's curve reached the asymptote (Figure 2), indicating that the sampling effort was sufficient to record the diversity of Odonata in the study region.

The NMDS ordination diagrams displayed a clear structure in odonate assemblages according to meso and microhabitats, and these differences were validated by PERMANOVA (mesohabitats: $p$ seudo-F=7.46; $\mathrm{R}^{2}=0.11 ; P=0.001$; microhabitats: pseudo-F $=5.16 ; \mathrm{R}^{2}=0.05$; $P=0.003)$. Argia, Brechmorhoga, Desmogomphus and Calopterygidae were associated with riffle, while Epigomphus, Heteragrion Phyllogomphoides, Perilestes, Remartinia and Rhionaeschna, by pool (Figure 3a). Argia, Brechmorhoga, Heteragrion and Phyllogomphoides were associated with stone 
Table 1. Abundance, richness and composition of immature stages of Odonata (Insecta) recorded in meso- and microhabitats in the studied streams in Santa Catarina Island, southern Brazil.

\begin{tabular}{|c|c|c|c|c|c|c|c|c|c|c|c|}
\hline \multirow{2}{*}{\multicolumn{3}{|c|}{$\begin{array}{c}\text { Conservation unit } \\
\text { Mesohabitat }\end{array}$}} & \multicolumn{5}{|c|}{ PMLP } & \multirow{2}{*}{\multicolumn{3}{|c|}{ UCAD }} & \multirow{4}{*}{ Total } \\
\hline & & & \multicolumn{2}{|c|}{ Riffle } & \multicolumn{2}{|c|}{ Pool } & \multirow{3}{*}{ Total } & Riffle & & \multirow{3}{*}{ Total } & \\
\hline \multicolumn{3}{|c|}{ Microhabitat } & 1 & $s$ & 1 & $S$ & & 1 & 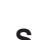 & & \\
\hline Suborder & Family & Genus & L & 0 & $\mathbf{L}$ & 0 & & L & 0 & & \\
\hline \multirow[t]{6}{*}{ Anisoptera } & Aeshnidae & $\begin{array}{l}\text { Remartinia Navás, } \\
1911\end{array}$ & & & 5 & & 5 & & & & 5 \\
\hline & & $\begin{array}{l}\text { Rhionaeschna } \\
\text { Förster, } 1909\end{array}$ & & 1 & 29 & 4 & 34 & & & & 34 \\
\hline & Gomphidae & $\begin{array}{l}\text { Desmogomphus } \\
\text { Williamson, } 1920\end{array}$ & 3 & & & & 3 & & & & 3 \\
\hline & & $\begin{array}{l}\text { Epigomphus Hagen } \\
\text { in Selys, } 1854\end{array}$ & & & 3 & & 3 & & & & 3 \\
\hline & & $\begin{array}{l}\text { Phyllogomphoides } \\
\text { Belle, } 1970\end{array}$ & & & 2 & 2 & 4 & & & & 4 \\
\hline & Libellulidae & $\begin{array}{l}\text { Brechmorhoga Kirby, } \\
1894\end{array}$ & 9 & 13 & 2 & 2 & 26 & 7 & 10 & 17 & 43 \\
\hline \multirow[t]{4}{*}{ Zygoptera } & Calopterygidae & & 38 & 2 & 3 & 2 & 45 & & & & 45 \\
\hline & Coenagrionidae & Argia Rambur,', 1842 & 7 & 3 & & 4 & 14 & & 7 & 7 & 21 \\
\hline & Heteragrionidae & $\begin{array}{l}\text { Heteragrion Selys, } \\
1862\end{array}$ & 4 & 8 & 23 & 10 & 45 & & 3 & 3 & 48 \\
\hline & Perilestidae & $\begin{array}{l}\text { Perilestes Hagen in } \\
\text { Selys, } 1862\end{array}$ & & & 6 & & 6 & & & & 6 \\
\hline Total & & & 61 & 27 & 73 & 24 & 185 & 7 & 20 & 27 & 212 \\
\hline \multicolumn{3}{|c|}{ Taxa richness } & 5 & 5 & 8 & 6 & 10 & 1 & 3 & 3 & 10 \\
\hline
\end{tabular}

Abbreviations of the Conservation units: PMLP = Municipal Park of Lagoa do Peri; UCAD = Desterro Environmental Conservation Unit. Abbreviations of the mesohabitats: $L=$ litter; $S=$ stone.

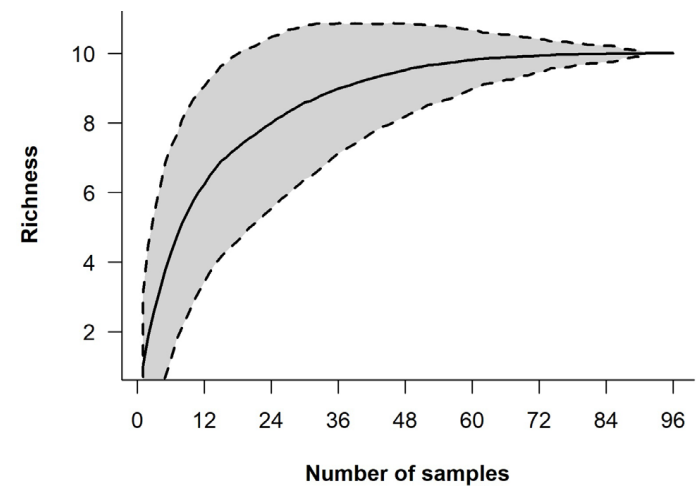

Figure 2. Cumulative richness of immature stages of Odonata (Insecta) in the Municipal Park of Lagoa do Peri (PMLP; Santa Catarina Island, southern Brazil). The grey shaded area within the dotted lines indicate $95 \%$ confidence intervals of the estimated values.

substrates, while Epigomphus, Perilestes, Remartinia and Calopterygidae were associated with litter (Figure 3b).

The final RDA model was significantly different from chance $\left(\mathrm{F}=1.962 \mathrm{R}^{2}\right.$ adj. $\left.=0.253 ; P=0.021\right)$. The two first axes summarized $25.3 \%$ of the variance in odonate composition, and accounted for $74.3 \%$ of the total the relationship with the environmental dataset. The first of RDA axis mostly segregated winter samples from the other seasons. In general, higher values of water temperature and stream
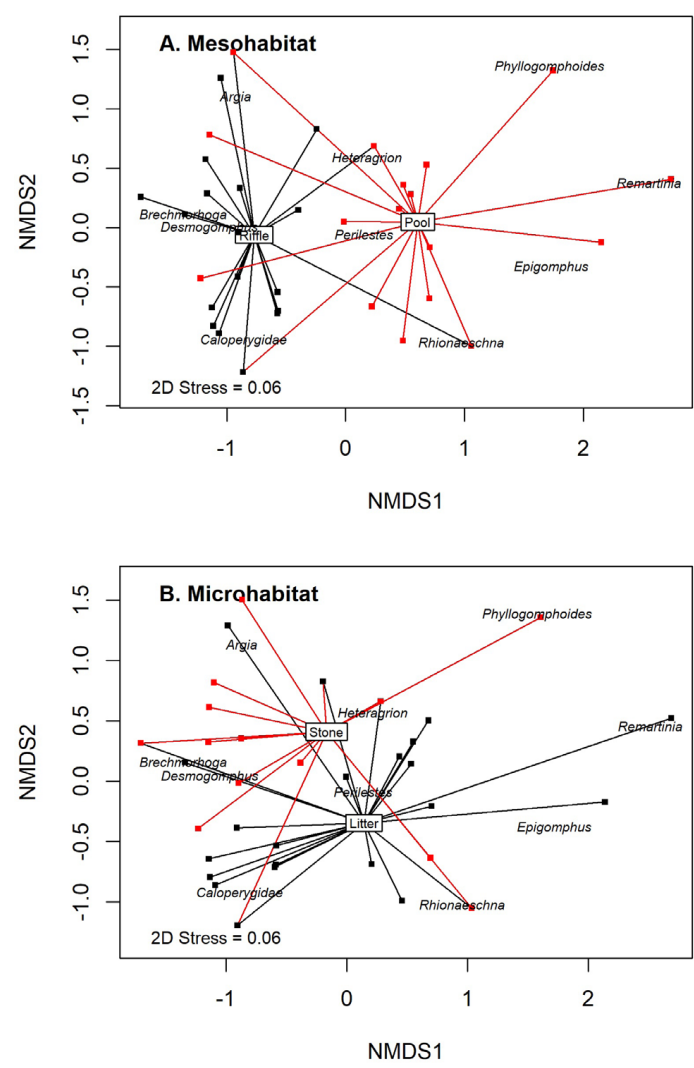

Figure 3. NMDS ordination diagrams of the composition of odonate assemblages according to (A) mesohabitats and $(B)$ microhabitats (stress $=0.06$ ) in streams in the island of Santa Catarina. 
(a)

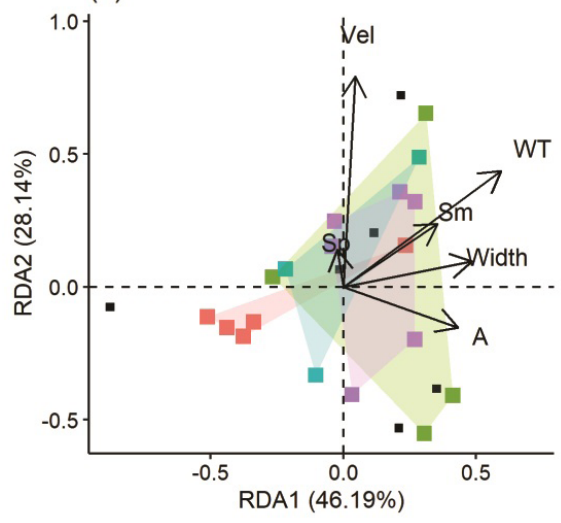

(b)

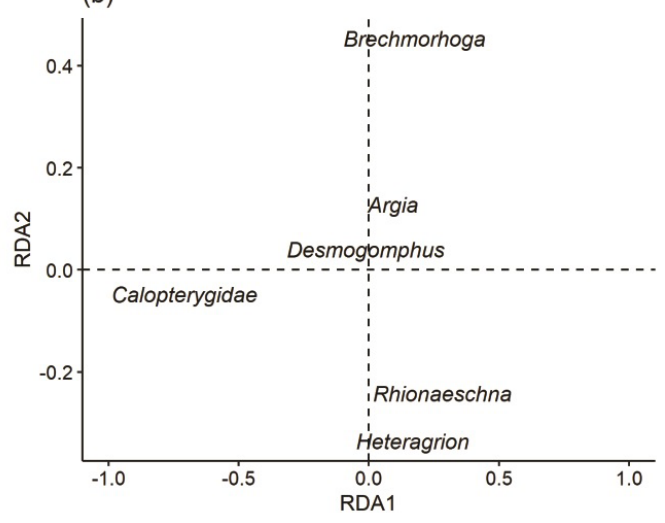

Figure 4. Redundancy Analysis ordination diagrams displaying the relationship of environmental drivers and the composition of odonate assemblages. a) triplot of environmental drivers (arrows), odonate taxa (dark squares) and sampling sites (colored according to the seasons); b) distribution of odonate taxa in the canonical space. The location of the filled squares in (a) corresponds to the location of the names of the odonate taxa in (b). Abbreviations in (a): $\mathrm{Vel}=$ stream velocity; $\mathrm{WT}=$ water temperature; $\mathrm{Width}=$ stream channel width; $\mathrm{Sp}=$ spring; $\mathrm{A}=$ autumn; $\mathrm{Sm}=$ summer .

width were associated with warmer seasons; the second RDA was positively associated with water velocity (Figure 4a). Some taxa were correlated with the environmental variables and seasons: Calopterygidae were more common in the winter, while Rhionaeschna and Heteragrion, in autumn; Argia and Desmogomphus, were more common in the warmer season. Brechmorhroga was positively correlated with water velocity (Figure 4a, b).

\section{Discussion}

\subsection{Inventory and diversity of Odonata in the study region}

The biodiversity of Odonata in the state of Santa Catarina is poorly known, and even genus-level inventories are rare in the literature. The revision and the family-level inventory conducted by Pires et al. (2015) recorded eight odonate families in Santa Catarina Island and in the state as a whole. The Taxonomic Catalogue of the Brazilian Fauna (CTFB) describes 39 valid odonate species from 23 genera in the state of Santa Catarina (Pinto, 2019). However, with information of the geographic distribution of Anisoptera genera provided by Garrison et al. (2006) and the records of Zygoptera species provided by Lencioni (2005, 2006) (posteriorly adjusted by the revision of Dijkstra et al., 2014) we were able to detect 57 genera from eleven families of Odonata for Santa Catarina state. Additionally, our results indicate new records of Desmogomphus Williamson, 1920, Epigomphus Hagen, 1854 (Gomphidae), Heteragrion (Heteragrionidae) and Perilestes Hagen, 1862 (Perilestidae) for the state.
In relation to the composition of dominant taxa, Calopterygidae and Heteragrion are common odonates in lotic systems (Costa et al., 2004). Their predominance is explained by their wide distribution in the Neotropical Region (Kalkman et al., 2008). On the other hand, the overall odonate genera richness in Santa Catarina Island is lower than other streams located in tropical and subtropical regions of the Brazilian territory. Pires et al. (2013) recorded 16 genera of immature odonates, while Renner et al. (2016a, b) recorded 13 and 15 genera of adult Odonata, respectively, in streams of the state Rio Grande do Sul (southernmost Brazil). Though the family richness is similar among these studies (from six to eight), it still corresponds to approximately one-third of the overall family richness recorded for the Neotropical Region (21; Kalkman et al., 2008).

The lower diversity observed in this study is probably due to two main reasons. First, the latitudinal diversity gradient observed for Odonata. Odonate richness is commonly higher in tropical regions of the globe, and tends to decrease towards higher latitudes (Kalkman et al., 2008). For instance, in comparison to streams from tropical regions in Brazil, studies record an overall odonate richness of no less than twenty genera (Ferreira-Peruquetti \& Fonseca-Gessner, 2002; Assis et al., 2004; Anjos-Santos \& Costa, 2006). Second, the insular condition of the study region might have prevented the occurrence of more taxa. The richness of insect groups is related to spatial isolation in islands (Dennis et al., 2008), and the effects of increasing distances on dispersal limitation of many aquatic insects have been described in the literature (Ligeiro et al., 2010; Siegloch et al., 2018). 
In the study region, the original Atlantic Forest vegetation has been largely fragmented (Klein et al., 2006; Bisheimer et al., 2013), increasing dispersal limitation and contributing to reduced richness of aquatic insects like odonates.

\subsection{Environmental drivers of the composition of Odonata}

Habitat structure played an important role in structuring assemblages of Odonata in the streams studied. Substrate type (litter and stone) and mesohabitats (riffle and pool) influenced the composition of immature stages of Odonata. The differential occupation of stream habitats by odonates is generally associated with their relationships with the aquatic vegetation and water flow regime (Corbet, 2004). The immature stages of odonate species that usually prefer either stronger or depositional areas in streams show large differences in the morphology and life habits associated with the adaptation to water current variation (Corbet, 2004; Suhling et al., 2015). In this study, Argia, Heteragrion and Calopterygidae showed preference by riffles. Their immature stages have elongated body shapes ('clasper' type), which favors attachment to substrate and enables their establishment in stronger water currents (Corbet, 2004). Argia and Heteragrion also had closer association with stone substrate. This finding agrees with previous studies that reported their occurrence in inorganic substrates in Brazilian streams (Carvalho \& Nessimian, 1998; Assis et al., 2004). Brechmorhoga showed preference by riffles and stone substrates. Immature stages of this genus have a sprawling body shape, which makes them well adapted to rithral areas (Carvalho $\&$ Nessimian, 1998; Assis et al., 2004). In fact, the detected influence of water velocity on odonate composition can be accounted by the close relationship of this genus with higher levels of stream discharge, as it was the genus positively correlated with water velocity.

In turn, most genera that preferred pool mesohabitats, such as Epigomphus, Phyllogomphoides (Gomphidae), Remartinia and Rhionaeschna (Aeshnidae), were also associated with litter substrates. This result can be explained by the relationship of immature odonates with aquatic vegetation (Carvalho \& Nessimian, 1998; Costa et al., 2004; Garrison et al., 2006). Accumulation of aquatic vegetation is more common in slower-flowing water (McCabe, 2011). In this sense, the immature stages of Aeshnidae, which have less active behaviors (Palacino-Rodríguez et al., 2018), generally occur more frequently in these habitats (Carvalho \& Nessimian, 1998). Immature stages of Aeshnidae and Gomphidae also have life habits associated with the aquatic vegetation, such as clinger habits (Carvalho \& Nessimian, 1998; Corbet, 2004; Garrison et al., 2006). In accordance, Perilestes showed preference by litter, and the occurrence of immature stages of this family in the aquatic vegetation is also recorded in the literature (Carvalho \& Nessimian, 1998). Desmogomphus (Gomphidae) was associated with riffles. This can be explained by the burrowing habit if this genus, which turns it well adapted to variable water currents lotic systems (Corbet, 2004; Garrison et al., 2006).

For some specific genera, our results represent records of new biological aspects regarding the occupation of meso and microhabitats. For instance, immatures of Phyllogomphoides were previously recorded in muddy and sandy streambeds of low-current streams (Costa et al., 2004; Garrison et al., 2006). In this study, this genus occurred in pool reaches and stone substrate. In addition, Desmogomphus, which was reported in inorganic substrates (sand and mud) and in strong-current waters (Costa et al., 2004; Garrison et al., 2006), was common in organic substrate (litter) and pool reaches in the streams studied. In this study, Perilestes which was previously recorded in strong waters, preferred pools. Immatures of Perilestidae were reported to show mobile as well as sessile life habits (Carvalho \& Nessimian, 1998), thus suggesting that the immature stages of this genus can be generalist regarding mesohabitat.

Other habitat structure variables that influenced the composition of immature stages of Odonata showed seasonal variation, such as water temperature. In fact, the composition of Odonata differed more strongly between winter and the other seasons. Most odonate taxa were associated with warmer periods of the year, while few taxa (Calopterygidae) occurred in winter periods. This result agrees with previous studies describing seasonal patterns in the assemblage structure of odonates in subtropical Brazil (Pires et al., 2014, 2019) and reinforces the importance of climate in structuring the occurrence of Odonata in stream ecosystems. Temperature is a strong driver of the life cycle of aquatic insects (Corbet et al., 2006), and is particularly important for odonates because it has an important role in larval development (Corbet, 
2004). Although very few studies have assessed the life cycles of immature Odonata in subtropical regions of Brazil, a recent study showed that the occurrence of species of Odonata inhabiting streams in southernmost Brazil was highly constrained in colder periods of the year, (Pires et al., 2019), thus explaining the positive association with the occurrence of most genera. Calopterygidae was the solely taxa that occurred in winter. They are reported to predominate in subtropical Brazilian streams (Pires et al., 2013). Although previous reviews suggested that few odonate species are able to overwinter and yield more than one generation in lotic ecosystems at moderate to high latitudes, some species of Calopterygidae were found to overcome this contingency (Corbet et al., 2006), thus being able to overwinter as immatures in non-tropical regions.

\section{Final Remarks}

The assemblages of immature stages of Odonata inhabiting the studied streams in the island of Santa Catarina had lower genera richness than tropical and subtropical Brazilian regions. This pattern is likely associated with the latitudinal gradient that influences the diversity of Odonata and to the insular condition of the study region (assumedly due to dispersal limitation effects). This study also provides new records of odonate genera for the state of Santa Catarina and subtropical areas of the Neotropical Region, as well as new biological notes regarding habitat use by odonate genera during their immature stage. Moreover, this study demonstrated the constraining effects of seasonal climate on the assemblage structure of stream odonates. In summary, our results are important for the understanding of the diversity and the ecology of freshwater insects inhabiting insular regions in the Brazilian territory.

\section{Acknowledgements}

The authors are grateful to Leonardo Lisboa, Rafael Schmitt, Aurea Lemes da Silva and Pedro Giovâni da Silva for their help in fieldwork. The authors thank the Conselho Nacional de Desenvolvimento Científico e Tecnológico - CNPq - for the post-doctoral scholarship (MCT/CNPq/CT-Hidro) received by A.E. Siegloch during the study period. M.I.M. Hernández received a Research Productivity grant from $\mathrm{CNPq}$ (number 303800/2010-0). M.M. Pires received a postdoctoral fellowship from $\mathrm{CNPq}$ (grant number 151152/2018-7). The authors are also grateful to
Universidade Federal de Santa Catarina (UFSC) and to the administration of the Municipal Park of the Lagoa do Peri for the logistical support provided.

\section{References}

ALLAN, J.D. and CASTILLO, M.M. Stream ecology: structure and function of running waters. Dordrecth: Springer, 2007. http://dx.doi.org/10.1007/978-14020-5583-6.

ANJOS-SANTOS, D. and COSTA, J.M. A revised checklist of Odonata (Insecta) from Marambaia, Rio de Janeiro, Brazil, with eight new records. Zootaxa, 2006, 1300(1), 37-50. http://dx.doi.org/10.11646/ zootaxa.1300.1.3.

ASSIS, J.C.F., CARVALHO, A.L. and NESSIMIAN, J.L. Composição e preferência por microhábitat de imaturos de odonata (Insecta) em um trecho de baixada do Rio Ubatiba, Maricá-RJ, Brasil. Revista Brasileira de Entomologia, 2004, 48(2), 273-282. http://dx.doi.org/10.1590/S008556262004000200017.

BAIN, M.B. and STEVENSON, N.J. Aquatic habitat assessment: common methods, Bethesda: American Fisheries Society, 1999.

BISHEIMER, M.V., SANTOS, C. and CARLSON, V.E. A mata atlântica da ilha de Santa Catarina. Florianópolis: Lagoa Editora, 2013.

BLANCHET, G., LEGENDRE, P. and BORCARD, D. Forward selection of spatial explanatory variables. Ecology, 2008, 89(9), 2623-2632. http://dx.doi. org/10.1890/07-0986.1. PMid:18831183.

BONNET, A. and QUEIROZ, M.H. Estratificação vertical de bromélias epifíticas em diferentes estádios sucessionais da Floresta Ombrófila Densa, Ilha de Santa Catarina, Santa Catarina, Brasil. Revista Brasileira de Botanica, 2006, 29(2), 217-228.

CARVALHO, A.L. and NESSIMIAN, J.L. Odonata do estado do Rio de Janeiro, Brasil: hábitats e hábitos das larvas. In: Nessimian, J.L. and A.L. Carvalho, eds. Ecologia de insetos aquáticos. Rio de Janeiro: PPGE/ UFRJ, 1998, pp. 3-28. http://dx.doi.org/10.4257/ oeco.1998.0501.01.

CORBET, P.S. Dragonflies: behaviour and ecology of Odonata. Colchester: Harley Books, 2004.

CORBET, P.S., SUHLING, F. and SOENDGERATH, D. Voltinism of Odonata: a review. International Journal of Odonatology, 2006, 9(1), 1-44. http:// dx.doi.org/10.1080/13887890.2006.9748261.

COSTA, J.M., SOUZA, L.O.I. and OLDRINI, B.B. Chave para as famílias e gêneros das larvas de Odonata citadas para o Brasil: comentários e registros bibliográficos. Publicaçoes Avulsas do Museu Nacional, 2004, 99, 1-43.

DELGADO, C. Spatial and temporal distribution patterns of Odonata larvae in the streams of a terra 
firma forest of the Central Amazon, Brazil. Journal of Freshwater Ecology, 2002, 17(4), 555-561. http:// dx.doi.org/10.1080/02705060.2002.9663933.

DENNIS, R.L.H., DAPPORTO, L., SHREEVE, T.G., JOHN, E., COUTSIS, J.G., KUDRNA, O., SAARINEN, K., RYRHOLM, N. and WILLIAMS, W.R. Butterflies of European islands: the implications of the geography and ecology of rarity and endemicity for conservation. Journal of Insect Conservation, 2008, 12(3-4), 205-236. http://dx.doi.org/10.1007/ s10841-008-9148-3.

DIJKSTRA, K.D.B., KALKMAN, V.J., DOW, R.A., STOKVIS, F.R. and TOL, J.V. Redefining the damselfly families: a comprehensive molecular phylogeny of Zygoptera (Odonata). Systematic Entomology, 2014, 39(1), 68-96. http://dx.doi. org/10.1111/syen.12035.

FERREIRA-PERUQUETTI, P.S. and FONSECAGESSNER, A.A. Comunidade de Odonata (Insecta) em áreas naturais do cerrado e monocultura no nordeste do estado de São Paulo, Brasil: relação entre o uso do solo e a riqueza faunística. Revista Brasileira de Zoologia, 2002, 20(2), 219-224. http://dx.doi. org/10.1590/S0101-81752003000200008.

FIGUEIREDO, N.S.B., PIRES, M.M., DAVANSO, R.C.S. and KOTZIAN, C.B. Diversidade de larvas de Odonata (Insecta) da Bacia do Rio Ibicuí, Rio Grande do Sul, Brasil. Ciência e Natura, 2013, 35(2), 84-94.

FONTES, M.L.S., MAROTTA, H., MACINTYRE, S. and PETRUCIO, M.M. Inter-and intra-annual variations of $\mathrm{pCO} 2$ and $\mathrm{pO} 2$ in a freshwater subtropical coastal lake. Inland Waters, 2015, 5(2), 107-116. http://dx.doi.org/10.5268/IW-5.2.726.

GARRISON, R., ELLENRIEDER, N.V. and LOUTON, J.A. Dragonfly genera of the new world: an illustrated and annotated key to the anisoptera. Baltimore: John Hopkins University Press, 2006.

HOFMANN, T. and MASON, C.F. Habitat characteristics and the distribution of Odonata in a lowland river catchment in eastern England. Hydrobiologia, 2005, 539(1), 137-147. http://dx.doi. org/10.1007/s10750-004-3916-1.

INSTITUTO NACIONAL DE METEOROLOGIA - INMET. Normais Climatológicas do Brasil 19812010 [online]. Brasília, 2018 [viewed 25 Oct. 2019]. Available from: http://www.inmet.gov.br/portal/ index.php? $\mathrm{r}=\mathrm{clima} /$ normaisClimatologicas

KALKMAN, V.J., CLAUSNITZER, V., DIJKSTRA, K.D.B., ORR, A.G., PAULSON, D.R. and TOL, J.V. Global diversity of dragonflies (Odonata) in freshwater. Hydrobiologia, 2008, 595(1), 351-363. http://dx.doi.org/10.1007/s10750-007-9029-x.

KLEIN, A.H.F., MENEZES, J.T., DIEHL, F.L., ABREU, J.G.N. and POLETTE, M. 2006. Erosão e progradação do litoral brasileiro - Santa Catarina.
In: D. Muehe, ed. Erosão e progradação do litoral brasileiro. Brasília: Ministério do Meio Ambiente, 2006, pp. 401-436.

LEGENDRE, P. and LEGENDRE, L.F.J. Numerical ecology. Amsterdã: Elsevier, 2012.

LENCIONI, F.A.A. Damselflies of Brazil: an illustrated identification guide. I - Non-Coenagrionidae families. São Paulo: All Print, 2005.

LENCIONI, F.A.A. Damselflies of Brazil: an illustrated identification guide. II - Coenagrionidae. São Paulo: All Print, 2006.

LIGEIRO, R., MELO, A.S. and CALLISTO, M. Spatial scale and the diversity of macroinvertebrates in a Neotropical catchment. Freshwater Biology, 2010, 55(2), 424-435. http://dx.doi.org/10.1111/j.13652427.2009.02291.x.

LISBOA, L.K., LEMES, A.L.S., SIEGLOCH, A.L., GONÇALVES-JÚNIOR, J.F. and PETRUCIO, M.M. Temporal dynamics of allochthonous coarse particulate organic matter in a subtropical Atlantic Rain Forest Brazilian stream. Marine and Freshwater Research, 2015, 66(8), 674-680. http://dx.doi. org/10.1071/MF14068.

LONGO, M. and BLANCO, J.F. Patterns at MultiSpatial Scales on Tropical Island Stream Insect Assemblages (Gorgona Island Natural National Park, Colombia, Tropical Eastern Pacific). Revista de Biología Tropical, 2014, 62(1), 65-83. http://dx.doi. org/10.15517/rbt.v62i0.15979.

MARCH, J.G., BENSTEAD, J.P., PRINGLE, C.M. and SCATENA, F.N. Damming tropical island streams: problems, solutions, and alternatives. Bioscience, 2003, 53(11), 1069-1078. http://dx.doi. org/10.1641/0006-3568(2003)053[1069:DTISPS ]2.0.CO;2.

MARCO JUNIOR, P. and VIANNA, D.M. Distribuição do esforço de coleta de Odonata no Brasil - subsídios para escolha de áreas prioritárias para levantamentos faunísticos. Lundiana, 2005, 6, 13-26.

MCCABE, D.J. Rivers and streams: life in flowing water. Nature Education Knowledge, 2011, 3, 19.

MENDES, T.P., LUIZA-ANDRADE, A., CABETTE, H.S.R. and JUEN, L. How does environmental variation affect the distribution of Dragonfly Larvae (Odonata) in the Amazon-Cerrado Transition Zone in Central Brazil? Neotropical Entomology, 2017, (in press). http://dx.doi.org/10.1007/s13744-0170506-2. PMid:28285400.

NASCIMENTO, R. Atlas ambiental de Florianópolis. Florianópolis: Instituto Larus, 2002.

NEW, T.R. Insect Conservation and Islands. Dordrecht: Springer, 2008 http://dx.doi.org/10.1007/978-14020-8782-0.

OKSANEN, J., BLANCHET, F.G., FRIENDLY, M., KINDT, R., LEGENDRE, P., MCGLINN, D., MINCHIN, P.R., O'HARA, R.B., SIMPSON, 
G.L., SOLYMOS, P., STEVENS, M.H.H., SZOECS, E. and WAGNER, H. Vegan: Community Ecology Package. $R$ package version 2.4-3 [online] 2016. [viewed 25 Oct. 2019]. Available at: https:// CRAN.R-project.org/package $=$ vegan

PALACINO-RODRÍGUEZ, F., PALACINO, D.A., RACHE-RODRÍGUEZ, L., CORDERORIVERA, A., PENAGOS, A.C. and LAMELASLÓPEZ, L. Larval development and behavior of Rhionaeschna marchali Rambur (Anisoptera: Aeshnidae) under captivity conditions. International Journal of Odonatology, 2018, 21(1), 55-70. http:// dx.doi.org/10.1080/13887890.2018.1437478.

PERES-NETO, P.R., LEGENDRE, P., DRAY, S. and BORCARD, D. Variation partitioning of species data matrices: estimation and comparison of fractions. Ecology, 2006, 87(10), 2614-2625. http://dx.doi. org/10.1890/0012-9658(2006)87[2614:VPOSDM ]2.0.CO;2. PMid:17089669.

PINTO, A.P. Odonata in Catálogo Taxonômico da Fauna do Brasil [online]. Brasília: PNUD, 2019 [viewed 25 Oct. 2019]. Available from: http://fauna.jbrj.gov.br/ fauna/faunadobrasil/171

PIRES, J.R., LISBOA, L.K., SILVA, A.L.L., PETRUCIO, M.M. and SIEGLOCH, A.E. Levantamento taxonômico e caracterização do hábitat de insetos aquáticos em Unidades de Conservação de uma ilha subtropical. Biotemas, 2015, 28(3), 57-67. http:// dx.doi.org/10.5007/2175-7925.2015v28n3p57.

PIRES, M.M., KOTZIAN, C.B., SPIES, M.R. and NERI, D.B. Diversity of Odonata (Insecta) larvae in streams and farm ponds of a montane region in southern Brazil. Biota Neotropica, 2013, 13(3), 259-267. http://dx.doi.org/10.1590/S167606032013000300028 .

PIRES, M.M., KOTZIAN, C.B. and SPIES, M.R. Diversity and Spatiotemporal Distribution of Larval Odonate Assemblages in Temperate Neotropical Farm Ponds. Journal of Insect Science, 2014, 14(275), 1-14. http://dx.doi.org/10.1673/031.014.84.

PIRES, M.M., KOTZIAN, C.B., DALZOCHIO, M.S., SGANZERLA, C., PRASS, G. and PÉRICO, E. Diversity of Odonata (Insecta) in Seasonal Deciduous Forest fragments in southern Brazil (state of Rio Grande do Sul), with a new record for the state and comments on the seasonal distribution of the species. Biota Neotropica, 2019, 19(4), e20190769. http:// dx.doi.org/10.1590/1676-0611-bn-2019-0769.

R CORE TEAM. $R$ : A language and environment for statistical computing [online]. Vienna, Austria: R Foundation for Statistical Computing, 2017. Available at: https://www.R-project.org/.

RAMÍREZ, A., ENGMAN, A., ROSAS, K.G., PERESREYES, O. and MARTINÓ-CARDONA, D.M.
Urban impacts on tropical island streams: Some key aspects influencing ecosystem response. Urban Ecosystems, 2012, 15(2), 315-325. http://dx.doi. org/10.1007/s11252-011-0214-3.

RENNER, S., PÉRICO, E. and SAHLÉN, G. Effects of exotic tree plantations on the richness of dragonflies (Odonata) in Atlantic Forest, Rio Grande do Sul, Brazil. International Journal of Odonatology, 2016a, 19(4), 1-13. http://dx.doi.org/10.1080/13887890. 2016.1251343.

RENNER, S., PÉRICO, E. and SAHLÉN, G. Man-made lakes form species-rich dragonfly communities in the Brazilian Atlantic Forest (Odonata). Odonatologica, 2016b, 45, 35-154.

SANTOS, G.F., SILVA, J.T.N., MENDONÇA, M. and VEADO, R.W.A. Análise ambiental da Lagoa do Peri. Geosul, 1989, 4(8), 101-123.

SIEGLOCH, A.E., SCHMITT, R., SPIES, M.R., PETRUCIO, M.M. and HERNÁNDEZ, M.I.M. Effects of small changes in riparian forest complexity on aquatic insect bioindicators in Brazilian subtropical streams. Marine and Freshwater Research, 2016, 68(3), 519-527. http://dx.doi.org/10.1071/MF15162.

SIEGLOCH, A.E., SILVA, A.L.L., SILVA, P.G. and HERNÁNDEZ, M.I.M. Local and regional effects structuring aquatic insect assemblages at multiple spatial scales in a Mainland-Island region of the Atlantic Forest. Hydrobiologia, 2018, 805(1), 61-73. http://dx.doi.org/10.1007/s10750-017-3277-1.

SOARES, J.A.C., BATISTA-SILVA, V.F., BONETO, D.D., BAILLY, D., ABELHA, M.C.F. and OLIVEIRA, I.A.D.V. Assembleia de imaturos de Odonata (Insecta, Anisoptera) em riachos sulmatogrossenses: implicações espaciais. Iheringia. Série Zoologia, 2015, 105(3), 325-332. http://dx.doi. org/10.1590/1678-476620151053325332.

SUHLING, F., SAHLÉN, G., GORB, S., KALKMAN, V., DIJKSTRA, K. and TOL, J.V. Order Odonata. In: J.H. THORP and A.P. COVICH, eds. Thorp and Covich's Freshwater Invertebrates - Volume I: Ecology and General Biology. Cambridge: Academic Press, 2015, pp. 893-932. http://dx.doi.org/10.1016/ B978-0-12-385026-3.00035-8.

THORP, J.H. and COVICH, A.P. Ecology and Classification of North American Freshwater Invertebrates. 3rd ed. San Diego: Academic Press, 2010.

Received: 20 June 2017 Accepted: 28 November 2019 